CuPAUAM. 20, 1993, pp. 133-145

\title{
THE ARCHAEOLOGICAL EVIDENCES OF THE EARLY PERIOD OF MILITARY CONTACTS BETWEEN THE BLACK SEA NORTH LITTORAL AND THE ANCIENT EAST AND THE "CIMMERIAN PROBLEM"
}

VLADIMIR ERLIJ

Museo de Arte Oriental. Moscú

NOTA: Los nombres y titulos rusos, que aparecen en el texto y en la Bibliografia, se dan en trasnliteración española (véase Calonge, 1969). El texto ingles se ha mantenido tal y como fue entregado por cl autor.

\section{Abstract}

The author distinguishes the archaeological evidences of the early military contact of The Black Sea North Littoral with the Ancient Near East, belonged to the group of the Novocherkassk-hoard type. He proposes what such evidences presents the most adequate archaeological conformity to the Assirian written evidences about the Cimmerians of the Sargon II era.

Key words. Cimmerians. Skythians. Chariots.

\section{Resumen}

El autor destaca los testimonios arqueológicos de los contactos militares mas antiguos en el litoral Norte del Mar Negro y en el Próximo Oriente de la época preescita.

Supone, que estos testimonios, pertenecientes al grupo del tipo del tesoro de Novocherkassk, son los que corresponden más adecuadamente desde el punto de vista arqueológico, a los testimonios escritos más antiguos de los asirios de época de Sargon II sobre los cimerios.

Palabras clave. Cimerios. Escitas. Carros de combate.

Since the last century there have been two tradition on the origin of the Cimmerians shown in the historical literature. The first tradition, which follows the information provided by Herodotus and other 
Greek authors, proposed that the Cimmerians inhabited Black Sea North littoral before the invasion of the Skythian. In addition to the legend of the Cimmerians, Herodotus pointed out existence of contemporary "Cimmerian" toponyms in this region: "The Cimmerian Bosphorus", "Cimmerian banks", region of "Cimmeria" (Her.IV.12.).

Among the archaeological literature the conception of the North Pontic origin of the Cimmerians was most consistent in a monograph of Alexey Terenozhkin "The Cimmerians" (Terenozhkin, 1976). He referred all pre-Scythian complexes $8 \mathrm{ht}-7 \mathrm{th}$ cent. B.C. of The Steppe and The Forest-Steppe of Ukraine to the Cimmerian culture. Terenozhkin also included in this culture two groups of nomadic population remains: the Chernogorovka and the Novocherkask ones. Complexes of Novocherkask hoard's type group presented in The South-East of Europe were picked out earlier by Aleksandr lessen (lessen, 1954). Now the idea of existence of the Cimmerian archaeological culture is supported by majority of Russian and Ukrainian archaeologists.

On the other hand, in the last 20 years a series of issues revising many aspects of the Cimmerian problem and reviving the tradition that had rejected the Pontic origin of Cimmerians were published.The Italian scholar Umberto Cozzoli proposed that tradition told by Herodotus and the "Cimmerians" toponyms were brought by the Greeks from Asia Minor, and they were used because North Pontic barbarians were similar to the real Cimmerians of Asia Minor (Cozzoli, 1968).

These ideas were developed in M.Salvini and A.Kristensen's works, published in 80 s. The main argument of these authors was the absence in Assyrian inscriptions of direct mentions of the coming of the North the Cimmerians from The Caucasus.

Later information from the Assaraddon time placed The Cimmerians in The Country of Manna. That's why, Salvini and Kristensen suggested the search of the fatherland of the Cimmerians, firstly mentioned in sources of Sargon time, in The East and Sourh-East of Urartu (Salvini, 1984; Kristensen, 1988). Anna Kristensen believed that the Cimmerian tradition and the toponyms were brought in Black Sea North Littoral by the Scythians who acted jointly with Cimmerians in the 7th cent. B.C. in Asia Minor. This point of view is close to the propositions of some Russian scholars such as Irina Kuklina (Kuklina, 1984, 56), Andrei Alekseev and Nataliia Kachalova (Alekseev, Kachalova, 1989), Sergei Tojta$s^{\prime}$ ev (Tohtas'ev, 1992). They refured the existence of the Cimmerian culture in the North Pontic region. Igor' D'iakonov supposed that "The Cimmerians" were not ethnic group. He translated "Gammiri" the Iranian languages into Assyrian texts as any "mobile detachment of horsemen" (D'iakonov, 1981).

In our article we'll try to examine one problem, closely connected with Cimmerians: the problem of the archaeological evidences of early military contacts of the Novochercask group with countries of the Ancient East.

Considerable findings made in the $70 \mathrm{~s}$ in The Northern Caucasus permitted to review until a high degree the Early Scythian chronology by comparing with the Neo-Assyrian one (Petrenko, 1980, 1983). In contemporary time the new early date 650-625 B.C. for the most important Scythian monuments the Kelermesskaia and Krasnoe Znamia barrow cemeteries, is supported by most scholars.

The following investigation leads to the accumulation of archaeological evidences from the contacts of Northern Caucasus and North Pontic region with Middle East and Trans-Caucasian area In the pre-Scythian times. Generally speaking, these evidences were not new. In 50-60s findings of horse-bits of Middle East form were published together with details of harness similar to the ones on Assyrian reliefs. All of them were found in The Forest-Steppe region of Ukraine (Titenko,1954, 78, fig.1-3; 
Kovpanenko, 1956, 174-179). Even earlier some findings of fragmentary helmets of Assyrian-Urartian forms were known in the cemeteries of Faskau and Verhnia Rutha (in The Norther - Caucasus) (Uvarova, 1909, 227; Kozenkova, 1990, 79 - fig. 8, 20).

The increase of such material created the necessity of recording, dating and going into a deeper study of these findings. it; more correctly explain it.

Almost all the artefacts are writing about belong to the armament and harness fields. They can be devided into two groups.

Within the first group we distinguished objects, which were directly adopted from Assyria and Urartu and which had derails of armour and helmets. Now we can't say exactly whether these objects were brought from The Middle East or Urartu or made in The Caucasus from imported original. In the local culture these artefacts had not any protorypes, however they had been known to The South of The Caucasus a long time before. Some Bronze pieces of scaly armour were found in several graves of the pre-Scythian (Novocherkassk) time in The Northern Caucasus: the cemetery "Industriya-1", grave 4; the grave near Kaban-gora; the cemerery Klin-lar, grave 16 (all from the region of Kislovodsk); Zaiukovskiy and Psedah Cemeteries (Checheno-Ingushetija); the Uashljitu barrow (Adygeia) (Vinogradov, Runich, Mihallov, 1976, fig. 5,21; Afanasjev, Kozenkova, 1981, 152-153; Dudarev, 1991, 50). Besides that, in the cemetery "Industria" together with the armour they were also discovered long and narrow bronze "scales", which could be considered as the details of an armour belt (Vinogradov, Runich, Mijailov, 1976, fig. 5, 22).

All of these finds permitted to revise the date of appearance of scale armour in The South-Eastern Europe, which was suggested by Evgeni Chernenko (6th cent. B.C.) (Chernenko, 1968), and to support the opinion of Valentina Kozenkova of belonging this data to The End of 8th cent. B.C.(Kozenkova, 1982). But the supposition of Chernenko about Assyrian origin of the scale armour of the Scythians could now be confirmed by new evidences.

Apart from the above mentioned bronze helmer from Fakau and Verhnia Rutha, now we know other two ones in the cemetery Klin-lar (Kielovodek city) Both helmets belong to the type of conichelmets with ear plate represented in the Assyrian reliefs (Fig. 1,3 ) (Belisnkiy, 1990, 193, fic 3,1; Dudarev, 1992, plate 17).

Groups of objects created in the local culture, without any doubt, under the Middle Eastern and the Transcaucasian influence, are distinguished in the second group of evidences. It meant "the import of ideas".

The type of horse bits with fasted cheek-pieces "Endzhe-Konstsntinovka" is included into these innovations (type IV of our classification) (Erlij, 1991). It was presented not only in The Northern Caucasus, but in The Forest-Steppe region of Ukraine. The Northern Caucasus (Novocherkassk) basis for this type is obvious. The shape of these horse-bits, character of their ornaments, blades and "hats" of cheek-pieces are the confirmation of this idea.

On the other hand, Middle Asian manner of fasted cheeck-pieces were used in this bridles. In the contemporary time the series of finds of horse-bits of this type consist of 8 objects. Two bits from Chishjo (Adygeja) (Tov, 1990, 40, fig 1; 41, fig.2) (Fig.1,1) are known to have been found in the Northern Caucau territory ; one finding from the city Maikop area was mentioned by Alexander lessen (Iessen, 1953, 92), one specimen was found near Krasnodar ( reported by Dmitriy Vasilinenko). There are 3 speciment of this type of bits from the Ukrainian Forest-Steppe region: The Teremtci, The Konstsntinovka, barrow mound N 375 and from The Museum of Kiorvograd (Gorishni, 1978, 56, fig.1 ; Titenko, 1954, 79, fig.5). One object of this type was found in Endzhe (Bulgaria) (Popov, 1932, 101, fig. 88). It seems, what the center of production of this type of bits was The Trans-Kuban region of The Northern Caucasus. 


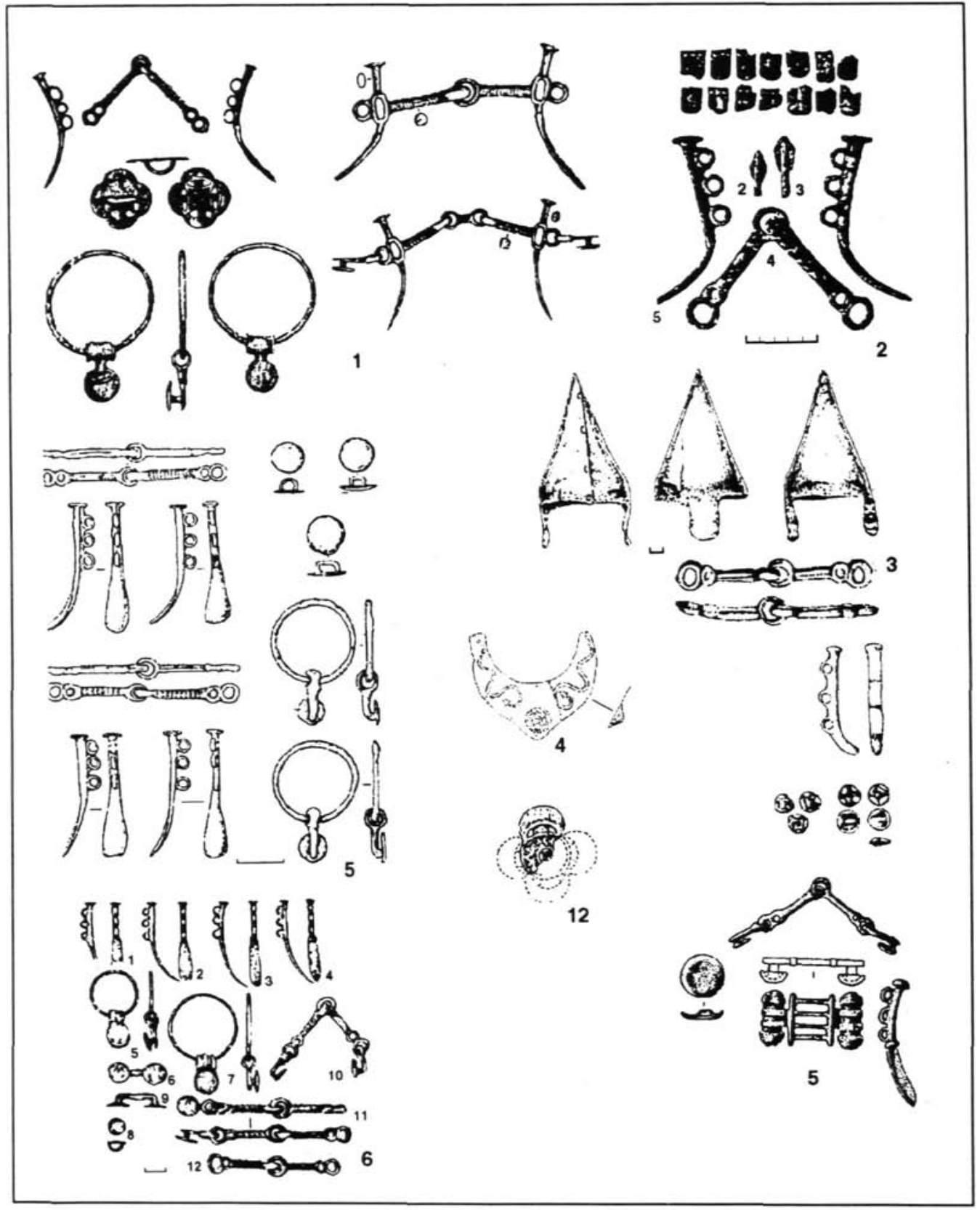

Figure 1. The early horizon of complexes: 1 . Cnishjo ; 2. Kaban-Gora; 3. Klin-Uiar, grave 186; 4. KlinUiar (surface find); 5. Kladi, barrow 46; 6. Pshish hoard; 7. Nosachovo 
Other finding of horse-bits with fasted cheek-pieces are known from the Trans-Kuban region to the East: coming from Koban and Tereze cemeteries (lessen, 1953, 70, fig. 1 -, 1; Kozencova, 1989, 186, plate XXXIX). But these shapes of artefacts were not developed in a separate type.

The same kind of innovation was produced by the appearance of chariots and chariot's harness among the group of "Novocherkask- hoard type".

They could be distinguishable after the research in 1988 of the barrow Uash'kitu near Kabekhabl Adygeia, Trans-Kuban region) .

Under the mound of this barrow was discovered the 13 meter long and 7 meter wide pit-grave (Fig.3). Although the funeral place in the grave was plundered in ancient times, remains of chariots were preserved in situ. A reconstruction of them showed that the arrangement of the team was similar to Assyrian one, which is well-known by reliefs. There was a two-wheeled chariot with one draught-pole linked to a four-horsed team under one yoke. The bronze equipment of team consisted of a pair of rings with pendants, a pair "bracelet-shaped rings", same plates of horse-traces etc. (Fig. 4 ). These objects could have been created on the local basis after the acquaintanceship of the Assyrian and the Urartian army, headed by charioteers. Now we know more than 20 complexes with details of chariots in The Northern Caucasus and The Ukranian Forest-Steppe region. Two complete of such chariots harness were found in Central Europe in Komliod and Priud hoards (Hallus, Horvath, 1939, plate XX; Kemenczei,1981, 31, fig.5,3); one object was found in the horse grave Norshun-Tepe (Anatolia) (Hauptman, 19\$3, fig. 4,9) (Fig.5,10).

The appearance of North Caucasian "pectorals", apparently used as a poitrel belongs to such group of innovations. Maria Pogrebova underlined the local features of these series of artefacts and their differences from the Urartian poitrel (Pogrebova, 1984, 20-23). Most probable center of production of these objects, which appeared as the result of adopting this idea, was the region of city Kislovodsk. They were introduced in the hoard from Beshtau-mount, in Sultan-gora and KIln-Yiar cemeteries (all 5 specimens) (Iessen, 1954, fig. 13; Vinogradov,1972,fig. 9,2; Dudarev, 1991, plates 15; 16,4) (Fig.1,4) Furthanmore, such "pectorals" were found in Transcaucasian, in the area of the Kolhida culture (two objects from Esheri and Anuhva) (Kuftin, 1949, fig. 31; Domanskiy, 1979, fig. 137). Most probably, they were imported from Northern Caucasus.

As for the characteristic of the contacts with The Middle East and Transcaucasian it's necessary to point out the following. If evidences of contacts among the first group (helmets and armour) could have appeared as a result of import, the innovations of the second group clearly demonstrated the acquaintance of the local population with the army of Assyria and Urartu. Both groups of evidences could be created as a result of a military campaign from the North Caucasian territory.

All the complexes with the evidences of contacts can be chronologically divided into on upper and early horizons. The upper horizon belongs to the so-called "pre-Kelermesskaiya (by lessen, 1954) or "transmission" (by Illinskaiya and Terenozhkin, 1983) group. It was distinguished by the presence of the Scythian arrowheads of a rhombic outline "Endze-Gabotin" type (by Polin, 1987) and cheek-pieces with three holes "Sialk B" (by Erlij, 1992). These types had a Central Asiatic(Siberian) origin and were connected with the first wave of Scythians. The upper date of this horizon is limited by the beginning of the Kelermesskaya period. Now it's dated to 650-625 B.C. by the time of I Krasnoznamenskiy barrows where a plate of a chariot's pole with image of goodness Ishtar was found, such images were presented on Assyrian reliefs of Assyrbanipal's rime (Petrenko, 1980). In the upper chronological horizon we included, Ush'kitu, Kvitki, hutor Alekseevskly and orher complexes (Fig.2). 


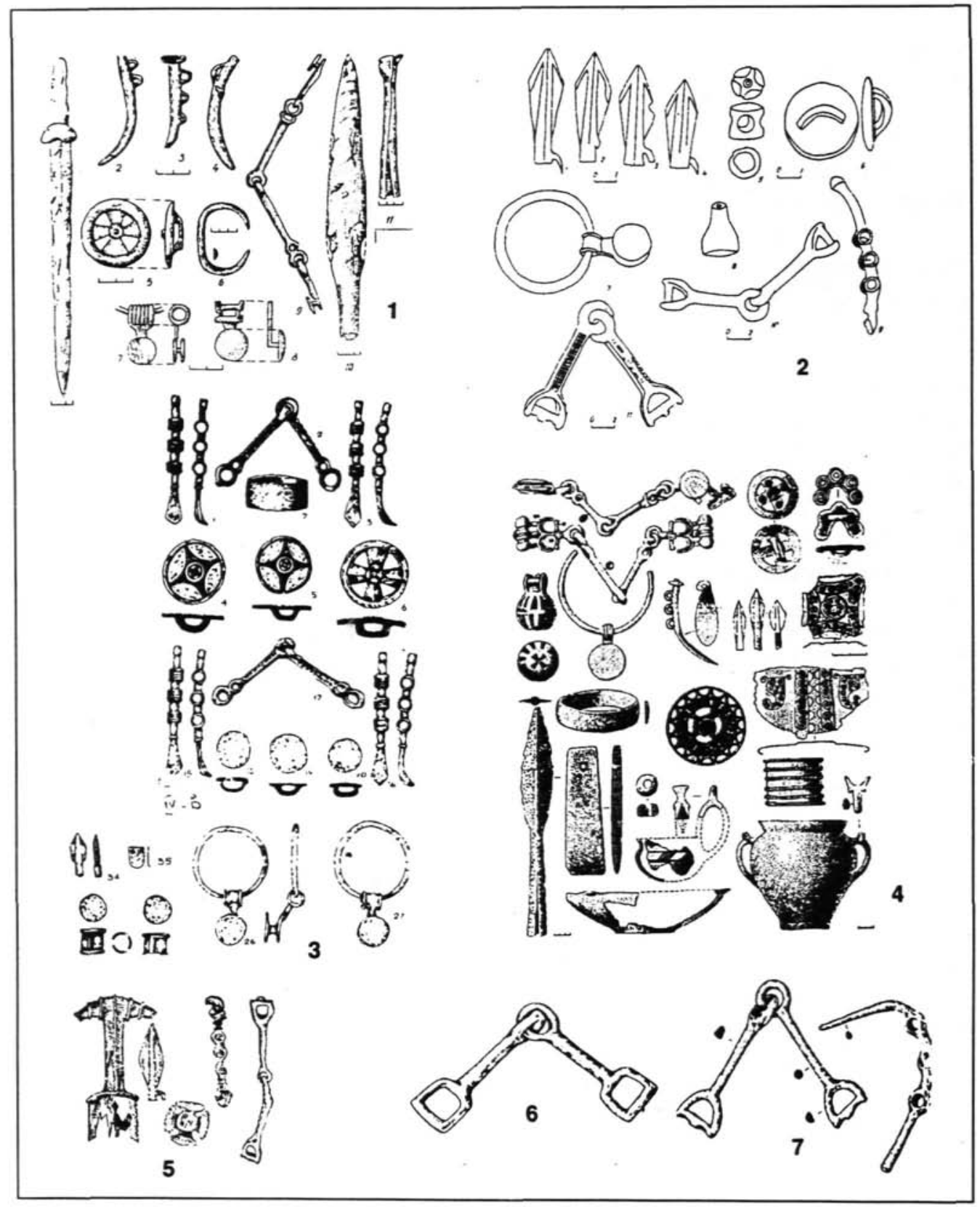

Figure 2. The upper horizon of complexes. 1: Lermontovskii raz'ezd; 2: Alekseevskii; 3: Uashkjitu; 4. Kvitki; 5. Kubanski cemetery, grave 35; Psish cemetery (surface find); Dukmasov (Surface find) 


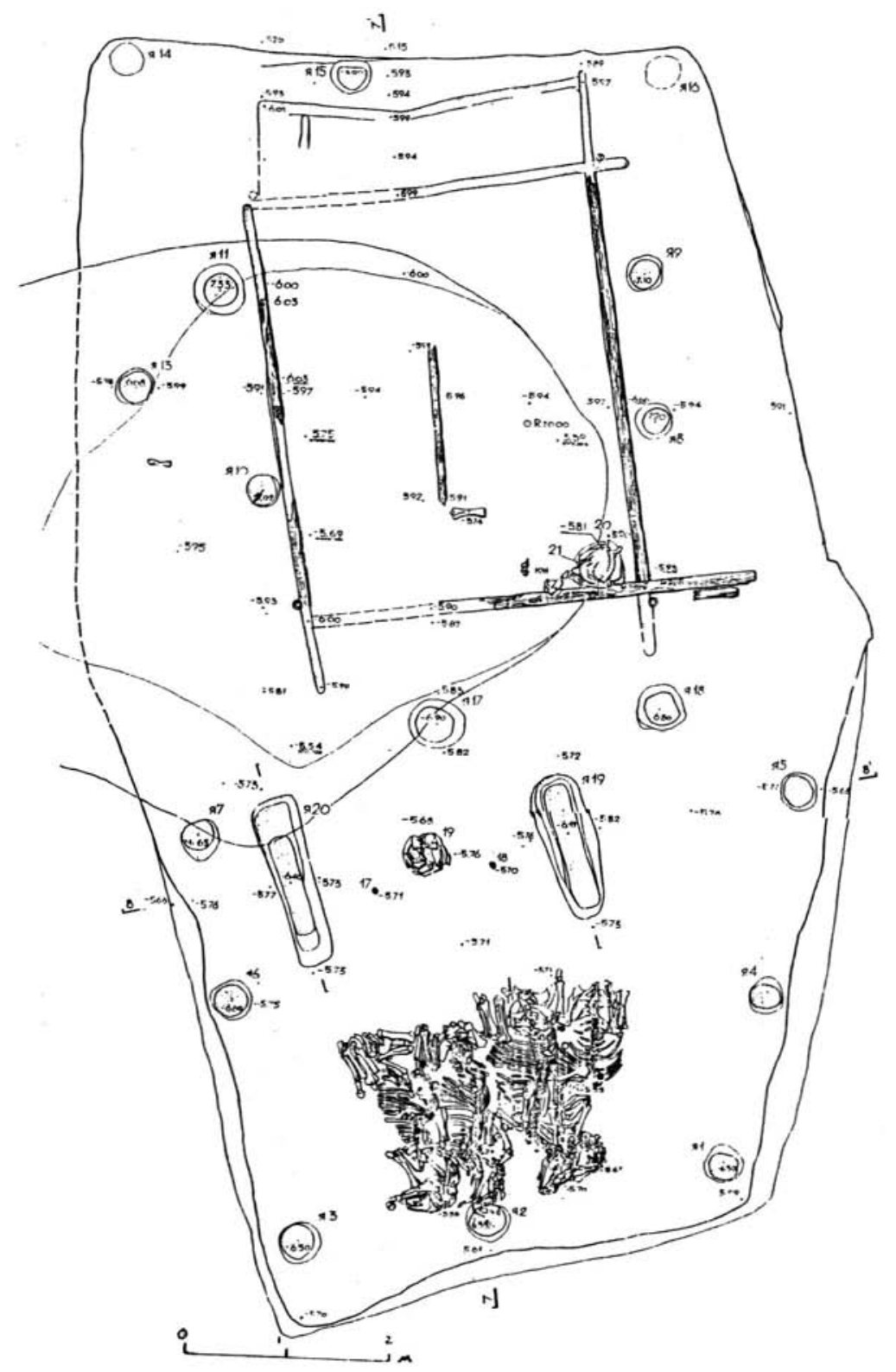

Figure 3. Uashjitu barrow. Plan of grave 


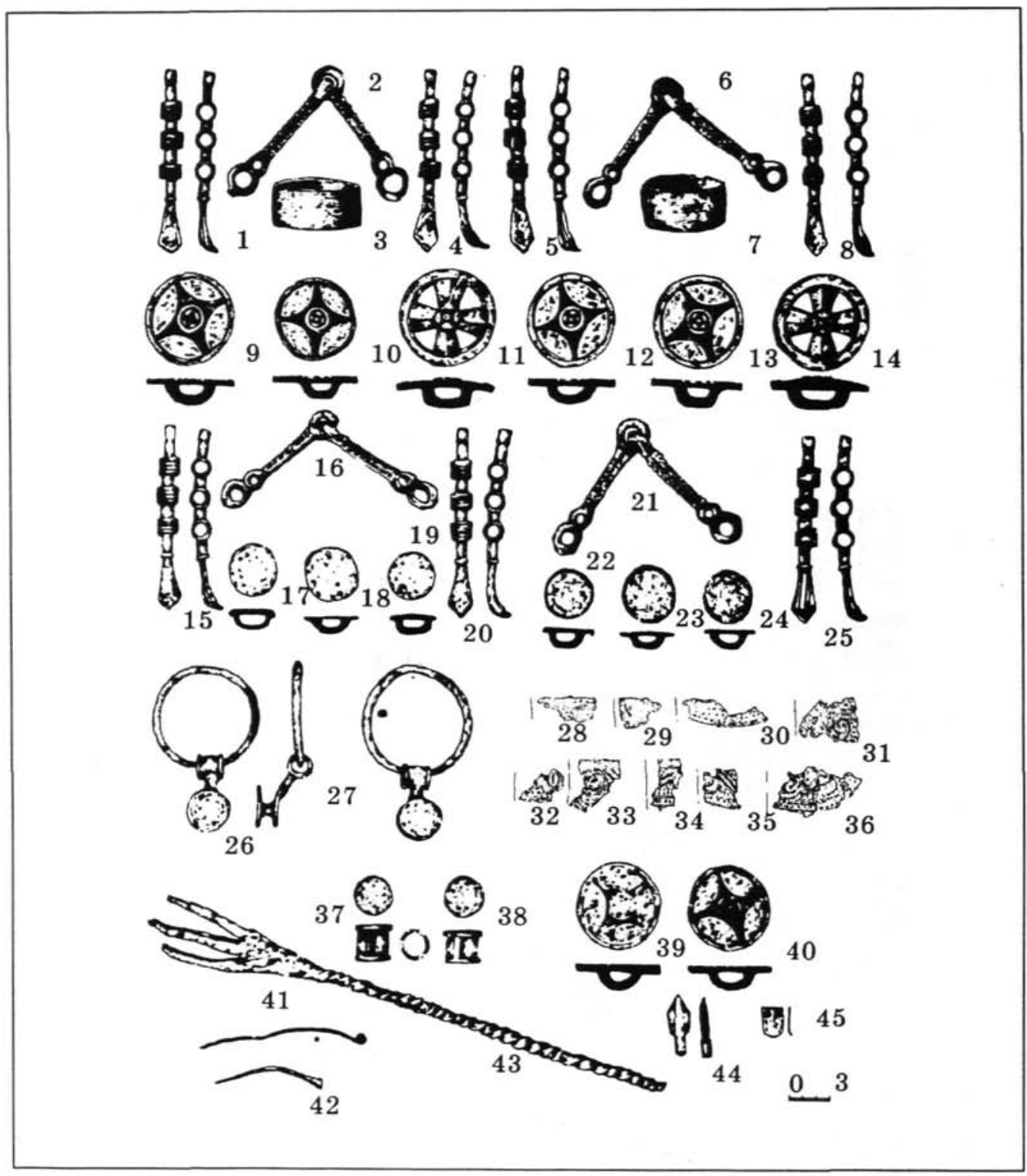

Figure 4. Uashjiu barrow. Contents of the grave

In the early horizon the Scyhtian types of artefacts are absent (Fig.1). This horizon can be dated by the Assyrian helmet from the grave 186 in Klin-Uiar cemetery (Belinski, 1990) (Fig.1,3) and the horse 
fastening from Nosachevo (Kovpanenko, 1966). The helmet from Klin-Ular belongs to type A-2 (by Tarik Madhloom) of Assyrian helmets, hammered from one piece of bronze, they existed during the time of Tyglatpalasar III (744-725 B.C.) and Sargon II (722-21 - 705 B.C). The same helmet as from KlinUiar we can be seen on the reliefs of Palace of Tiglatpalasar III (Barnett, Falkner, 1962, plate LIV).

The horse fastenings from Nosachevo were widely dated to the time of Sargon II to Assurbanipal by Galina Kovpanenko (Kovpanenko, 1966, 177-178). But Georg Kossak in two of his issues pointed out, that such fastening were present on reliefs of Tiglalpalasar III (744-727 B.C) (Kossack, 1987, 116; Idem., 1987a).

In grave 186 of Klin-Uiar cemetery some cheek-pieces of a not yet classic "Novocherkask" form were found with helmet. These belonged to pre-Novocherkask "transmission" type I-g (Erlijh, 1992); and the contents of this grave, most probably, marks the beginning of campaign, which we dated to The last quarter of the 8 th cent. B.C. This date can be compared with the first information about the Cimmerians found in Assyrian narrative sources. This can be connected with unsuccessful campaign of Urartian king Rusa I into the country of Gamir. The time of this campaign has now been successfully dated by the scholars Anna Kristensen and Askold Ivanchik to year the 714 year B.C. (Kristensen, 1988, 42; Ivanchik, 1989, 6; Idem., 1990, 6-8). According to the the source shows the military contacts with The Cimmerian in that period were limited to the territory of Urartu and Western Assyria. It can be supported by some findings of the Novochercask period in The South of The Caucasus.

The upper horizon of complexes with evidences of contacts corresponds chronologically to the Assyrian sources of The first half of 7th cent. B.C. In Assarhaddon's appeals to the oracle of Shamash (680-670 B.C) it was mentioned that alternately Cimmerians and Scythians, were acting in The East of Assyria together with the Mannaens and the Medes. As Igor' Diakonov and Askold Ivanchik supposed in this situation the name "Cimmerians" were used in inscriptions for Scythians or Sake (Diakonov, 1981, 93; Ivanchik, 1989, 7). The Cimmerians were properly located by different sources at that time in region of Kilikia and Kapoddokia.

It was published nor long ago Anatolian complexes Imirler (near Amasia) and Norshun-Tepe, dated to the first half of the 7th cent. there in this time were Cimmerians) with had a mixed character. There were the elements of "Scythian triad", connected by origin with The East of Eurasia, horse bits with stirup-shaped terminations, rhomb-shaped arrowhead and beaked axe. The word "akinake" and the ring of the chariot's harness were connected with the North Caucaus; and with Transcaucasian the bits made of twisted bronze bars (Unal, 1982, 65-81; Hauptmann, 1985, fig 4; 10).

It is very probable that these complexes display a mixture of the two nomad's waves: are coming from the Asiatic Part of the Steppe and the other from The Northern Caucasus. It may also be an Asiatic wave called "Scythians" ("Shkuza" and "Shkuda" of Assyrian sources).

The main argument of the archaeologists against the Black Sea North Littoral origin of The Cimmerians is the absence in The South of The Caucasus of artefacts of the Novocherkassk period. Such finds, in fact, were not numerous. Alexander lessen mentioned the bits with double-ring endings from Surmushi and fragments of Novocherkask's type cheek-piece from Canyon of Ksan (Georgia) (Iessen, 1953, 64). Above, we have referred to the charior's harness details from Norshun-Tepe. Besides that horse bits are known from grave 47 in the cemetery of Kalakent (Azerbaijan). They have been created under obvious influence of the Novocherkask-type bits. They have bended blades like the Novocherkask ones (Nagel y Strommenger, 19-35, fig.19) (Fig.5,13). 


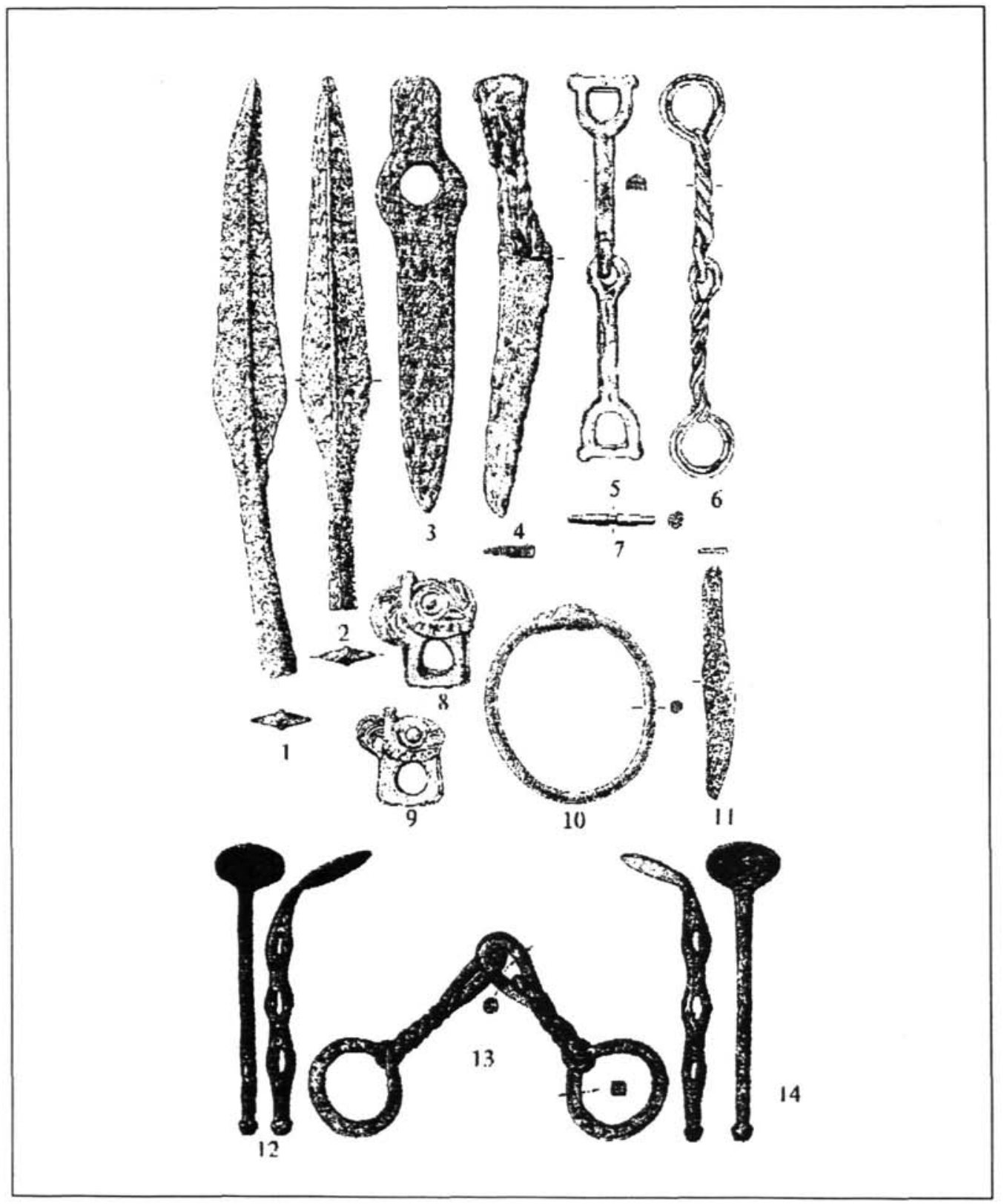

Figure 5. 1-11. Norsnun-teoe (Anatolia), horse grave b y Hauptmann (1985); 12-14. Kalakent, grave 47 by Nagel and Strommenger (1985) 
Therefore we can't speak about a full absence of the Novocherkask impact in The Near East. Obviously, since the military campaign of tribes from The Northern Caucasus territory were sporadically and of short duration, they couldn't leave significant remains. On the other hand, it is necessary to carry out a special investigation for the findings of objects of the pre-Scytian time as it was with the Scytian ones.

Apparently, the Novochercask hoard's type group on contemporary level of our knowledge preents the most adequate archaeological conformity to the Assyrian written evidences about Cimmerians on the Sargon time. Early military contacts with Middle East make us treat more attentively the North Pontic tradition defending the Cimmerians origin, and not reject it at all. It is necessary to look for some real basis in the Herodotus legend about the Cimmerians.

\section{BIBLIOGRAFIA}

AfANAS'EV, G. E., y KOZENKOVA, V. I.,1981: "O ne izvestny pogrebal'n yjkomplesaj predskiskogo vremeni iz okrestnostei Kislovodska" (Sobre los complejos de enterramientos desconocidos de la epoca pre-escita de los alrededores de Kislovodsk), Sovietskaia Arjeologiia, N.o 2, Moscu.

Alekseev, A. IU., y KaChalova N, K., 1990: "O kimmeritsaj v Severnom Prichernomor'e " (Sobre los cimerios en el litoral Norte del Mar Negro), Tezisy dokladov konferentsii "Problemy skifo-sarmatskoi arjeologii Severnogo Pichernomor'ia" , Zaporozh'e.

AleKSeEv, A. IU., 1992: Skifskaia jronika (Cronica escira), San Petersburgo.

BARNETT , R. D., y FAL.KNER, M., 1962: The Sculprures of Tiglath-Pileser III (745-727 B.C.) from the Central and South-West Palaces of Nimrud, London.

BELINSKI, A. B., 1990: "K voprosu o vremeni poiavleniia shlemov assirii' skogo tipa na Kavkaze" (Sobre el tema del momento de la aparicion de los cascos del tipo asirio en el Caucaso), Sovietskaia Arjeologiia-4, Moscu.

CALONGE, JULIO, 1969: Trancripcion del ruso al español, Madrid.

CHERNENKO, E. V., 1968: Skifskii dospej (La armadura escita).

Cozzolı, U., 1968:"I Cimmeri", Studi publicati dell'Instituto Italiano per la Soria Antica, fasc. ventesimo, Roma.

DUDAREV, S. L., 1991: Iz istorii sviazei naseleniia Kavkaza s kimmeriisko-skiffkim mirom (De la historia de las relaciones de la poblacion del Caucaso con el mundo cimerio-escita), Groznyi.

ERLIJ, V. R., 1991: "Bronzovye uzdechnye nabory i problema jronologii kompleksov predskifskogo i ranneskifskogo vremeni Zakuban "ia" (Juegos de brida de bronce y el problema de la cronologia de los complejos de la epoca pre-escita y escita temprana en Trans-Kuban), Drevnosti Severnogo Kavkaza i Prichernomor'ia, Moscu.

GorishNII, P. A., 1978: "Bronzovi vudila z s.Teremtsi" (Bocados de bronce de la aldea de Teremtsi), Arjeologia 27, Kiev.

HallptMaN, H., 1985: Neue Funde eurasischer Steppennomaden in Kleinasien, Beitrage zur Altertumskunde Kleinasien, Mainz. 
IESSEN, A. A., 1953: " K voprosu o pamiatnikaj VIII- VII vv. do n.e. na iuge Evropeiskoi chasti SSSR" (Sobre el tema de los monumentos de los ss. VIII-VII a.C. en el Sur de la parte europea dela URSS), Sovietskaia Arjeologiia, XVIII, Moscu.

- 1954: "Nekotorye pamiatniki VIII-VII vv. do n.e. na Severnom Kavkaze (Algunos monumentos de los ss. VIII-VII a.C. en el Caucaso del Norte), Voprosy Skifo-sarmatskoi arjeologii, Moscu.

IL'INSKAIA, V. A., y TF.RFNOZ.HKIN, A. I., 1983: Skifia VII-III vv. do n.e. ( Escitia de los ss. VII-III a.C.), Kiev.

IVANCHIK, A. I., 1989: Kimmeriitsy v Perednei Azii ( Los cimerios en el Proximo Oriente), Avtoref. kand. ist. nauk, Moscu.

- 1990 "Kimmeriitsy i Urartu nakanune vos'mogo pojoda Sargona II" (Los cimerios y Urartu en vispera de la octava campana militar de Sargon II), Vestnik Drevnei Istorii, 3, Moscu.

KOSSACK, G., 1987: " Fremdling in Fars", Archaologische Mitteilungen aus Iran , 20, Berlin.

- 1987a: "Von den Aufangen des skytho-iranischen Tierstils", Skythika, Munchen.

KONZENKOVA, V. I., 1982: Tipologia i jronologicheskaia klassifikatsiia predmetov Kobanskoi kul'tury. Vostochnyi variant (Tipologia y clasificacion cronologica de los objetos de la cultura de Koban. Variante Oriental), Moscu.

- 1986: "Psedajskii mogil'nik kobanskoi Kul'tury" (El enterramlento dePedajenla cultura de Koban),Novoe v arjeologii Severnoqo Kavkaza, Moscu.

- 1989: Kobanskaia Kul'tura. Zapadnyi variant (La culturade Koban. Variante Occidental), Moscu.

- 1990: "Jronologiia Kobanskoi kul'tury: dostizheniia, opyt, utochneniia, nereshennye problemy" (La cronologia de la cultura de Koban: exitos, experiencia, puntualizaciones, problemas no resueltos), Sovietskaia arjeologiia, 3, Moscu.

KOVPANENKO, G. T., 1966: "Nosachivskii kurgan VIII-VII st. do n.e." (El tumulo de Nosachevo de lo ss. VIII-VII a.C.), Arjeologiia, 20, Kiev.

KRISTENCEN, A., 1988: Who were the Cimmerians, and where did they come from? Sargon II, the Cimmerians and Rusa I. Cophenhagen.

KUFTIN, B. A., 1949: Materialy k arjeologii Koljidy (Materiales para la arquelogia de Koljida), t.1, Tbilisi.

KUKLINA, I. V., 1985: Ernografiia Skifii po antichnym istochnikam (Etnografia de Escitia segun fuentes clasicas), Leningrado.

MADHLOOM, T., 1970: The chronology of Neo Assyrian Art, London.

NAGEL, W., y STrommenger, E., 1985: Kalakent, Berlin.

PETRENKO, V. G., 1980: "Izobrazhenie boqini Ishtar iz kurgana v Stavropol'e" (La representacion de la diosa Ishtar en un tumulo de Stavropol'e), Kratkie soobshcheniia Instituta Arjeologii Akademii Nauk SSSR 162, Moscu.

- 1983: "Skifskaia kul tura na Severnom Kavkaze" (La cultura escita en el Caucaso del Norte), Arjeologicheskii sbornik Gosudarstvennogo Ermitazha 23, Leningrado.

Pogrebova, M. N., 1984: Zakavkaz'e i egosviazi s Perednei Aziei (El Transcaucaso y sus relaciones con el Proximo Oriente), Moscu.

POLIN, S. V., 1987: "Jronologiia rannoskifs'kij pam'iatok" (Cronologia de los monumentos escitas tempranos), Arjeologiia 59, Kiev. 
POPOV, R., 1932 "Mogil'nite grobove pri s. Endzhe" (Enterramientos en la aldea Endzhe), Izvestiia na Bolgarskiia Arjeologicheski institut, IV, Soifia.

SALVINI, M., 1884:" La Storia della regione in Epoca Urartea e I Documenti in Tra lo Zagros e Urmia", Ricerche Storiche ed archeologiche nell Azerbaingian iranio, ed. P.Percorella e M.Salvini, Incunabula Graeca, LXXYIII, Roma.

TERENOZHKIN, A. I., 1976: Kimmerii^tsy (Los cimerios), Kiev.

TrTENKO, G.T., 1954: "Zakavkazskie udila, naidennye na Poltavshchine" (Bocados del Transcaucaso, encontrados en Poltavshchina), Kratkie soobshechniia Instituta Arjeologii Akademii Nauk USSR, 3, Kiev

TOJTAS'EV, S. R., 1993: " K jronologii i etnicheskoi atributsii pamiatnikov skifskogo tipa na Blizhnem Vostoke i v Maloi Asii" (Para la cronologia y atribucion etnica de los monumentos del tipo escita en el Proximo y Cercano Oriente), Rossiiskaia arjeologiia, 2, 1993.

Tov, A. A., 1989: "Protomeotskii mogil'nik Chishjo bliz aula Tauijabl' v Teuchezhskom raione" (Enterramiento Protomeoto Chishjo junto al pueblo Tauijabl', en la region de Teuchezhsk), Meoty predki adygov, Maikop.

UNAL, V., 1985: " Zwei Graber eurasisicher Reiternomaden" Beitrage zur allgemeinen und Vergleichenden Archaologie, 4, Munchen.

Uvarova, P. 1909- Mogil'niki Severnogo Kavkaza (Enterramientos en el Caucaso del Norte), Materialy poarjeologii Kavkaza, VIII, Moscu

VINOGRaDOV, V. B., 1972: Tsentral'nyi i Severo-Vostochnyi Kavkaz v skifskoe vremia (El Caucaso Central y Noreste durante el periodo escita ), Groznyi.

Vinogradov, V. B.; RUNiCh A, P., y Mijallov, N. B., 1976: "Novoe o kobanskoi kul'ture Tsentral'nogo Predkavkaz'ia" (Algo nuevo sobre la cultura de Koban de la zona premontanosa del Caucaso Norte Central), Arjeologo-ernograficheskii sbornik, 4, Groznyi. 